\title{
PENGALIHAN HAK HADHANAH JATUH KEPADA BAPAK TERHADAP ANAK BELUM MUMAYYIZ (Studi Kasus di Pengadilan Agama Palangka Raya)
}

\author{
Transfer of Hadhanah's Right to Fall to Father Against Children Not Mumayyiz \\ (Case Study in Palangka Raya Religious Court)
}

\section{Sanawiah*}

Universitas Muhammadiyah Palangkaraya, Palangka Raya,

Central Kalimantan, Indonesia

*email: sanaw10@yahoo.co.id

\begin{tabular}{l} 
Kata Kunci: \\
Hak \\
Hadhanah \\
Mumayyiz \\
Keywords: \\
Rights \\
Hadhanah \\
Mumayyiz \\
Accepted \\
March 2019 \\
Published \\
June 2019 \\
\hline Cc) (i) ()
\end{tabular}

(C) 2019 The Authors. Published by Institute for Research and Community Services Universitas Muhammadiyah Palangkaraya. This is Open Access article under the CC-BY-SA License (http://creativecommons.org/licenses/by-sa/4.0/). DOI: https://doi.org//0.33084/anterior.vl8i2.808.

\section{PENDAHULUAN}

Pengaturan dalam agama Islam, mengenai rumah tangga merupakan dasar bagi kehidupan manusia dan merupakan faktor utama dalam membina masyarakat. Dari sebuah rumah tangga segala persoalan kehidupan manusia timbul (Matondang, 2014). Apabila perselisihan suami isteri itu menimbulkan permusuhan dan menimbulkan bibit kebencian antara keduanya sehingga tidak ada jalan lain, sedangkan ikhtiar untuk perdamaian tidak dapat disambung lagi, maka perceraian jalan satusatunya yang menjadi pemisah diantara mereka (Rozalinda \& Nurhasanah, 2014). Perceraian merupakan suatu perbuatan yang halal namun dibenci oleh Allah SWT, berdasarkan Hadist Nabi Muhammad SAW yang sering digunakan namun masih diragukan ke Sahihannya (Daradjat, 1995):

Yang artinya: "Sesuatu perbuatan halal yang paling dibenci Allah adalah thalaq/perceraian". 
Hadist tersebut menunjukkan bahwa perceraian merupakan alternatif terakhir (pintu darurat) yang dapat dilalui suami istri bila ikatan perkawinan tidak dapat dipertahankan keutuhan dan kelanjutannya. Suatu gugatan perceraian, bisa mengundang berbagai macam permasalahan.Di samping gugatan cerai itu sendiri, muncul pula masalah-masalah lain sebagai akibat dari dikabulkannya gugatan cerai tersebut, baik permasalahan harta bersama sampai permasalahan tentang siapa yang lebih berhak untuk melakukan hadhanah (pemeliharaan) terhadap anak (Azizah, 20I2). Dalam Kompilasi Hukum Islam Pasal 105 huruf (a) menyebutkan bahwa dalam hal terjadinya perceraian, pemeliharaan anak yang belum mumayyiz atau belum berumur 12 (dua belas) tahun adalah hak ibunya. Kemudian, dalam Pasal I56 huruf (a) akibat putusnya perkawinan karena perceraian ialah anak yang belum mumayyiz berhak mendapatkan hadhanah dari ibunya (Abdurrahman, 2007).

Dari ketentuan diatas, dapat kita lihat bahwa peranan ibu sangatlah penting terhadap anak yang belum mumayyiz apabila didalam rumah tangga terjadi perceraian. Adapun siapa yang lebih berhak mengasuh anak yang belum mumayyiz, bila kita melihat argumen di atas, maka yang berhak mengasuh anak yang belum mumayyiz adalah pihak ibu. Sebab, pada hakikatnya seorang ibu lebih mengetahui dan lebih mampu mendidiknya, juga karena ibu lebih mempunyai rasa kasih sayang dan kesabaran yang lebih dari pada bapak untuk melakukan tugas ini (Nuroniyah et al., 20II). Berdasarkan penjelasan yang telah disebutkan di atas, pada dasarnya anak yang belum mumayyiz jatuh ketangan ibu, tapi tidak demikian adanya yang terjadi di Pengadilan Agama. Hak hadhanah tersebut dialihkan kepada bapak. Menarik untuk ditelaah, dasar yang menjadi bahan pertimbangan bagi Hakim (Ratio Decidendi) untuk memutuskan pihak mana yang berhak mendapatkan hak hadhanah dengan segala aspeknya, baik dari hukum Islam maupun dari perundang-undangan.
Oleh karena itu penulis ingin menelusuri kasus tersebut yang mana dalam putusan Hakim memutuskan hak hadhanah kepada bapak walaupun anak tersebut belum mumayyiz, karena pada dasarnya anak yang belum mumayyiz adalah hak ibunya. Seorang Hakim mempunyai alasan-alasan dan pertimbangan yang digunakan untuk sampai kepada keputusannya atau dengan kata lain ini disebut Ratio Decidendi (Arkisman \& Hadi, 2018). Berdasarkan latar belakang ini, penulis tertarik untuk melakukan penelitian berjudul Pengalihan Hak Hadhanah jatuh Kepada Bapak terhadap Anak yang Belum Mumayyiz dengan putusan perkara yaitu Nomor 0067/Pdt.G/2018/PA Plk, yang dalam penelitian ini akan menganalisis apa saja pertimbangan Hakim dalam perkara hak hadhanah, dan apa Ratio Decidendi seorang Hakim dalam mempertimbangkan hak hadhanah di Pengadilan Agama Palangka Raya

\section{METODOLOGI}

Penelitian ini mengunakan jenis penelitian hukum Impiris kasus yang terjadi di lapangan, dengan pendekatan perundanag-undangan (statute approach), pendekatan historis (historical approach), pendekatan konseptual (conceptual approach), dan pendekatan profetik (prophetic approach). Pendekatan profetik merupakan pendekatan dengan basis instrument teks-teks yang bersumber dari wahyu yang diterima nabi dan rasul serta Sunnah.

\section{HASIL DAN PEMBAHASAN}

\section{Kebijakan Hakim dalam memutuskan perkara hadhanah di Pengadilan Agama Palangka Raya Nomor 359/Pdt.G/20 I 2/PA PIk}

Adapun Putusan Nomor 359/Pdt.G/20I2/PA Plk yang dikeluarkan oleh Pengadilan Agama Kota Palangka Raya, membagi hak pengasuhan ke-lima orang anak kepada ibu dan bapaknya, lebih jelasnya sebagai berikut: 
I. Anak pertama, umur I4 tahun, bahwa anak tersebut lahir pada tanggal 7 Juli 1998 yang berarti sudah berusia 14 tahun atau sudah 16 mumayyiz. Maka berdasarkan ketentuan Pasal 105 huruf b Kompilasi Hukum Islam dipersilahkan kepada anak tersebut untuk memilih diantara ayah (Tergugat) atau ibunya (Penggugat).

2. Anak Kedua umur 10 tahun, anak ke 3 umur 8 tahun, anak ke 4 umur 5 tahun ketiganya ditetapkan untuk ikut ibunya.

3. Anak kelima umur 4 tahun, ditetapkan ikut bapaknya (Tergugat).

Secara normatif dalam Kompilasi Hukum Islam apabila diamati Secara teoritis dalam Normatif Kompilasi Hukum Islam, Hakim memiliki kedudukan, kewajiban sekaligus memiliki peran yang sangat penting dalam membuat putusan sebagaimana telah dijelaskan di atas bahwa dalam hal menetapkan hadhanah, ada beberapa faktor yang bisa mempengaruhi keputusan Hakim itu sendiri. Adapun selanjutnya dalam Pasal 10 (I) UndangUndang Nomor 48 Tahun 2009 tentang Kekuasaan Kehakiman disebutkan :

"Pengadilan dilarang menolak untuk memeriksa, mengadili, memutu suatu perkara yang diajukan dengan dalil hukum tidak ada atau kurang jelas, melainkan wajib untuk memeriksa dan mengadilinya".

Putusan adalah hasil atau kesimpulan atau penyelesaian dari suatu pemeriksaan perkara yang didasarkan pada pertimbangan dan dasar yang menetapkan suatu hokum (Simorangkir et al., 2004). Putusan menurut Andi Hamzah yang dikutip oleh Abdul Manan adalah hasil akhir atau penyelesaian dari suatu perkara yang telah dipertimbangkan dengan berbagai dasar yang digunakan dalam mengambil keputusan tersebut yang diucapkan Hakim dalam bentuk tulisan. Kemudian definisi putusan menurut Sudikno Mertokusumo yang telah dikutip juga oleh Abdul Manan adalah suatu pernyataan yang diucapkan oleh Hakim yang berwenang untuk mengucapkan dalam sidang terbuka untuk umum sebagai akhir dari perkara kedua belah pihak yang berperkara (Siregar, 20I4; Manan, 2008).

Tugas dan Pertimbangan Hakim (Ratio Decindendi). Hakim dalam mengambil suatu keputusan merujuk pada Undang-Undang Nomor 50 Tahun 2009 tentang perubahan kedua atas Undang-Undang Nomor 7 Tahun 1989 tentang Peradilan Agama,yakni pasal 60A ayat (I) disebutkan "Dalam memeriksa dan memutus perkara, Hakim harus bertanggung jawab atas penetapan dan putusan yang dibuatnya". Selanjutnya dijelaskan pada ayat (2)“Penetapan dan putusan sebagaimana dimaksud pada ayat (I) harus memuat pertimbangan hukum Hakim yang didasarkan pada alasan dan dasar hukum yang tepat dan benar".

Seorang Hakim tidak luput dari tuntutan untuk kreatif dalam mempertimbangkan suatu masalah hukum, Undang-Undang Nomor 48 Tahun 2009 tentang Kekuasaan Kehakiman antara lain:

"Putusan pengadilan selain harus memuat alasan dan dasar putusan, juga memuat pasal tertentu dari peraturan perundang-undangan yang bersangkutan atau sumber hukum tak tertulis yang dijadikan dasar untuk mengadili”.

Berkaitan dengan hal ini maka Ratio Decidendi seorang Hakim akan menjadi dasar dalam mencari putusannya.

Ketika dianalisis dalam kenyataannya seorang ibu tersebut sanggup berpisah dengan anaknya tanpa memperhartikan kepentingan anaknya maka dapat disimpulkan hasil analisis bahwa bapaknya memiliki keperdulian, kemampuan dan kesanggupan dalam memelihara anak tersebut. Dari analisis berdasarkan hukum Non Yuridis (Meta Yuridis) yaitu kepentingan masa depan anak-anak yang merupakan kemaslahatan bagi anak tersebut, yang menjadi pertimbangan hukum tidak hanya didominasi oleh dasar hukum yang bersifat Yuridis, Non Yuridis namun juga dasar hukum Non Yuridis dengan melihat segi sosiologis, dan segi psikologis maupun materi dan non materi. 


\section{Kebijakan Hakim dalam memutuskan perkara hadhanah di Pengadilan Agama Palangka Raya Nomor 0067/Pdt.G/20I8/PAPIk}

Pertimbangan Hukum Menimbang, bahwa maksud dan tujuan gugatan Penggugat Bapak adalah sebagai penggugat dan Hakim Menimbang, bahwa sebelum memeriksa pokok perkara Majelis Hakim telah berusaha mendamaikan Penggugat dan Tergugat dan telah pula menunjuk mediator untuk memediasi Penggugat dan Tergugat namun upaya damai dan mediasi yang dilakukan tidak berhasil, maka ketentuan upaya damai dan mediasi yang dilakukan tidak berhasil, maka ketentuan Pasal 82 ayat (I) dan ayat (4) Undang-Undang Nomor 7 Tahun 1989 sebagaimana telah diubah dengan Undang-Undang Nomor 3 Tahub 2006 dan UndangUndang Nomor 50 Tahun 2009, Jo pasal 3 I ayat (I) dan (2) Peraturan Pemerintah Nomor 9 Tahun 1975, dan ketentuan Pasal 4 Peraturan Mahkamah Agung Nomor I Tahun 2016, telah dilaksanakan;

Menimbangkan, bahwa Penggugat dalam gugatannya pada pokoknya mendalikan sebagai berikut:

I. Bahwa Penggugat dengan Tergugat telah dikaruniai seorang anak dengan inisial DAR binti ME. Umur 4 tahun II bulan;

2. Bahwa dalam putusan perceraian Penggugat dengan Tergugat belum ditetapkan hak asuh anak dengan inisial DAR;

3. Bahwa selama ini anak Penggugat dengan Tergugat yang berinisial DAR binti ME umur 4 tahun II bulan diasuh oleh Penggugat dan karena Tergugat sebagai ibu kurang menunjukan sikap kasih sayang kepada anak dan kurang memperdulikan dan memperhatikan perkembangan psikologis anak dan untuk pendidikan anak dimasa depannya, karena itu Penggugat memohon agar hak hadhanah anak yang bernama DAR berada pada Penggugat;

Menimbang, bahwa Tergugat dalam jawaban dan duplikasinya pada pokoknya mendalilkan sebagai berikut:
I. Bahwa Tergugat mengakui dan membenarkan dalil Penggugat angka I, 2 di atas;

2. Bahwa Tergugat menolak dalil Penggugat pada angka 3 karena hal tersebut adalah dibuat-buat oleh Penggugat. Faktanya adalah suasana tersebut diciptakan Penggugat dan selalu menghalang-halangi Tergugat untuk bertemu dengan anak Tergugat yang belum Mumayyiz. Perbuatan Penggugat jelas-jelas dapat memisahkan secara fisik dan emosional anak dengan ibunya sehingga kasih sayang ibunya tidak tercurahkan secara maksimal kepada anaknya. Hal yang demikian adalah perbuatan tidak adil;

Majelis Hakim Menimbang, bahwa Penggugat telah berusaha meneguhkan dalil-dalilnya dengan mengajukan bukti tertulis P.I s/d P.6 serta 3 orang saksi;

Menimbang, bahwa bukti P.I (Fotokopi Akta Kelahiran) yang merupakan akta otentik dan telah bermaterai cukup dan cocok degan aslinya, isi bukti tersebut menjelaskan bahwa anak yang berinisial DAR lahir tanggal lahir 9 Februari 2013 adalah anak Penggugat (ME) dengan Tergugat (ES), isi bukti tersebut telah memenuhi syarat formal dan materil. Menimbang, bahwa oleh karena telah terbukti anak yang bernama DAR mempunyai hubungan yang baik dengan ayah dan ibunya demikian pula ayah dan ibunya sama-sama memberikan perhatian dan menyayangi anaknya DAR, sedangkan tidak terbukti Tergugat (ibunya) tidak cakap, mengabaikan atau mempunyai perilaku buruk, maka tidak cukup alasan untuk dapat mengalihkan hak yang berinisial DAR yang bernama Danesha Aida yang belum berusia 12 tahun kepada ayahnya, hal mana sesuai dengan keputusan dengan keputusan Mahkamah Agung Indonesia Nomor KMA/032/SK/IV/2006 tentang Penberlakuan Buku II Pedoman Pelaksanaan Tugas dan Administrasi Pengadilan. Halaman 156 angka 15.b yang menyatakan "Pemeliharaan anak yang belum berusia 12 tahun dapat dialihkan pada ayahnya, bila ibunya diangap tidak cakap, mengabaikan atau mempunyai perilaku buruk yang akan menghambat pertumbuhan jasmani, 
rohani, kecerdasan intelektual dan Agama anak" oleh karena itu maka gugatan Penggugat untuk ditetapkan Penggugat sebagai pemegang hak hadhanah anak yang berinisial DAR harus dinyatakan ditolak.

\section{KESIMPULAN}

Hakim dalam memutuskan perkara hadhanah di Pengadilan Agama Palangka Raya Nomor 359/Pdt.G/20 I2/PA Plk. Perkara Hadhanah jatuh kepada bapak terhadap anak yang belum mumayyiz. Sementara kebijakan Hakim dalam memutuskan perkara hadhanah di Pengadilan Agama Palangka Raya Nomor 0067/Pdt.G/2018/PA Plk. Gugatan Penggugat Bapak/Ayah sebagai pemegang hak hadhanah dinyatakan ditolak.

\section{REFERENSI}

Abdurrahman. 2007. Kompilasi Hukum Islam di Indonesia. Jakarta: Akademika Presindo.

Arkisman, A. \& Hadi, I. 2018. Aspek Yuridis Hak Asuh Anak Akibat Perceraian Orang Tua berdasarkan Undang-Undang Perkawinan dan Undang-Undang Perlindungan Anak (Studi Kasus Perkara No. 098/Pdt.G/2017/PA.Gs). Jurnal Pro Hukum: Jurnal Penelitian Bidang Hukum Universitas Gresik, 7, I-I5.

Azizah, L. 2012. Analisis Perceraian dalam Kompilasi Hukum Islam. Al-'Adalah, 10, 4I5-422.

Daradjat, Z. 1995. Ilmu Fiqih. Yogyakarta: Dana Bakti Wakaf.

Manan, A. 2008. Penerapan Hukum Acara Perdata di Lingkungan Peradilan Agama. Jakarta: Kencana.

Matondang, A. 20I4. Faktor-Faktor yang Mengakibatkan Perceraian dalam Perkawinan. JPPUMA: Jurnal Ilmu Pemerintahan dan Sosial Politik UMA (Journal of Governance and Political Social UMA), 2, $|4|-\mid 50$.

Nuroniyah, Wardah, \& Wasman. 20II. Hukum Perkawinan Islam di Indonesia: Perbandingan Fiqh dan Hukum Positif. Yogyakarta: Teras.

Rozalinda, R. \& Nurhasanah, N. 2014. Persepsi Perempuan Tentang Perceraian di Kota
Padang. Miqot: Jurnal Ilmu-ilmu Keislaman, 38, 395-4I6.

Simorangkir, J.C.T., Erwin, T.R., \& Prasetyo, J.T. 2004. Kamus Hukum. Jakarta: Sinar Grafika.

Siregar, R.E.A.A. 2014. Studi Tentang Peradilan Sesat (Rechterlijke Dwaling) dan Hubungannya dengan Memudarnya Kepercayaan Masyarakat terhadap Hukum. Fitrah: Jurnal Kajian Ilmu-Ilmu Keislaman, 8, 17-30. 